\title{
Understanding sexual violence in armed conflict: cutting ourselves with Occam's razor
}

Rosanne Marrit Anholt

\begin{abstract}
Sexual violence has been firmly put on the internal agenda of the humanitarian community. Despite commendable advances in both policy and practice, there continues to be a gap between what is recommended and the reality in the field.

In this paper, I argue that, notwithstanding the profound challenges of working in humanitarian emergencies, our understanding of sexual violence in conflict is watered down to such an extent that it impedes effective humanitarian action.

First, humanitarians' reductionist approach to sexual violence not only disregards victims/survivors other than the stereotypical but also exempts perpetrators from scrutiny_including the international humanitarian community itself, through whose extensive depoliticisation of sexual violence has erased the link between gender inequality and violence. Second, the international humanitarian community has positioned itself as the white, western, heroic protector of vulnerable women and girls (and not men and boys) - a narrative that not only escalates power differences between humanitarian and beneficiary but also reproduces the subordination of women.

Third, an exposé of silences in international discourses about sexual violence in armed conflict shows the humanitarian community's complicity in reproducing systems of gender inequality that allow for sexual violence to occur and remain unaddressed, by refusing to transform the restrictive political environment that ultimately impedes effective humanitarian action.

This analysis of humanitarian sexual violence discourses indicates a mismatch between the nature of the issue and the way in which it is understood, leading to ineffective programmes on the ground. Humanitarians' engagement with critical research, as well as researchers' engagement with feminism, may recreate meanings that benefit our understanding rather than impede it.
\end{abstract}

Keywords: Sexual violence, Armed conflict, Humanitarian action

Abbreviations: AU, African Union; DRC, Democratic Republic of the Congo; ICTR, International Criminal Tribunal for Rwanda; ICTY, International Criminal Tribunal for the former Yugoslavia; IDP, Internally displaced person; IS, Islamic State; NGO, Non-governmental organisation; RUF, Revolutionary United Front; UK, United Kingdom; UN, United Nations; US, United States 
Sexual violence is a severe human rights violation that 'happens in a place, and involves violent acts, perpetrators, victims, survivors and impacts ranging from health to a broad array of social consequences. Sexual violence is also a tool or strategy of war that encompasses the preconflict, conflict escalation and post-conflict phases. It breaks taboos, thereby violating rules and crossing thresholds that society sets on acceptable conduct [emphasis in original]' (Leatherman 2011, p. 9).

Sexual violence has long been known to occur during war, ${ }^{1}$ yet only since the world was exposed en masse to the atrocities committed during the Rwandan genocide (see, for example, Human Rights Watch 1996), and the dissolution of Yugoslavia-in particular the war in Bosnia and Herzegovina (see, for example, Carpenter 2006), has sexual violence in armed conflict started to receive international attention (Marsh et al. 2006; Palmer et al. 1999). The 1990s subsequently saw an explosive expansion of the number of humanitarian policies dealing with sexual and gender-based violence in conflict-affected populations (Palmer et al. 1999), including United Nations (UN) Security Council Resolutions that acknowledged not only gendered experiences of war but also the importance of addressing sexual violence in armed conflict (Barrow 2010; Engle 2014; Leatherman 2011; Scully 2009).

Despite these advances in the decision-making arena, large-scale perpetration of sexual violence continues in contemporary conflicts. The accounts of sexual violence in the protracted crisis in the Democratic Republic of the Congo (DRC) are a well-known example (Longombe et al. 2008). Here, sexual violence is repeatedly documented to the extent of producing a 'pornography of violence,' where media and researchers alike are 'trying to outdo each other with the most barbaric gang-rape scenario' (Stearns 2009, para 4). Although victims/survivors $^{2}$ of sexual violence may see little change after sharing their experiences, the even more recent and incessant media attention given to sexual violence perpetrated by the Islamic State (IS) in Syria and Iraq (Ahram 2015; Berenson 2014; 'Rape and sexual slavery' 28 August 2014) does indicate that sexual violence in armed conflict is now firmly placed on the international agen$\mathrm{da}-$ and the consciousness of the public in major donor countries.

The international humanitarian community-consisting of UN agencies; Red Cross and Red Crescent Societies; and non-governmental organisations (NGOs) providing immediate relief in protracted crises (armed conflict), loosely organised along ideological and functional lines-is increasingly less able to meet humanitarian assistance needs (ALNAP 2015), despite its enormous expansion over the last decades (Walker and Maxwell 2009). For sexual violence in conflict, this means, for example, that essential services for sexual violence victims/survivors are largely unavailable, inaccessible, and inadequate (Chynoweth 2008; Hakamies et al. 2008; Henttonen et al. 2008; Krause et al. 2015; Qayum et al. 2013). As Wayte et al. (2008) put it: 'there is a large gap between what is recommended and the reality in the field' (p. 90), even though sexual violence has severe physical, psychological, and social consequences for victims/survivors that extend to their families and communities-such as children born from rape (Isis-WICCE 2001; Krantz and Garcia-Moreno 2005; Longombe et al. 2008).

Notwithstanding the multiple challenges related to working in conflict zones and on war-time sexual violence in particular (Fast 2010; Jewkes et al. 2014; Leatherman 2011), and despite the highly commendable advances made, some explanations for the gap between policy and practice point to the international humanitarian system's 'inherent structural insufficiency' (ALNAP 2015. p. 14). An example of this concerns the cluster approach, a coordination mechanism that has been implemented in numerous humanitarian emergencies since the Humanitarian Reform in 2005 (Landegger et al. 2011; UNOCHA n.d.). Indeed, a number of scholars have suggested that prevention of and response to sexual violence in conflict is frustrated by the way in which humanitarian action is organised: no single agency, United Nations or otherwise, is demonstrating any clear leadership in addressing sexual violence (Marsh et al. 2006; McGinn 2009; Seybolt 2009).

This paper argues that the gap between humanitarians' promises of justice ('Remarks at the launch of the international protocol' 2014) and the lived reality of conflict-affected populations-including that of victims/survivors of sexual violence-is partly due to current (mis)understandings of sexual violence in armed conflict. Understanding shapes practice: the way in which sexual violence is conceptualised 'will have an impact on the way [...] those involved in interventions for 'prevention' or 'support of victims' behave and interact, which can in some circumstances be problematic' (Freedman 2014, p. 131). Therefore, this paper first explores international humanitarian discourses around sexual violence in armed conflict and its understanding of victims/survivors. Next, the paper analyses how the international humanitarian community positions itself in relation to sexual violence victims/survivors, as well as how it conceptualises its role in addressing sexual violence in conflict. Third, the paper explores silences in the international sexual violence discourse, in particular with regard to the way that obscured interests ensure that the status quo remains unchallenged. Finally, the significance of these results for humanitarian practice is discussed, and suggestions are made on how to move forward in order to arrive at a more realistic and attainable humanitarian action. 


\section{Understanding sexual violence in armed conflict: instrumentality, medicalisation, and depoliticisation}

The International Criminal Tribunal for the former Yugoslavia (ICTY) and the International Criminal Tribunal for Rwanda (ICTR) are commonly regarded as the events that put sexual violence in conflict on the international agenda (Marsh et al. 2006; Palmer et al. 1999; Scully 2009). The 1998 ICTR Jean Paul Akayesu case in particular has often been regarded as a historical achievement, as it successfully prosecuted rape as genocide (Haddad 2011; Scully 2009), despite the initial lack of readiness to do so (Haddad 2011). This and other landmark cases (see, for example, Engle 2005) nevertheless helped transform sexual violence in conflict from an 'unfortunate but inevitable byproduct of war' (Scully 2009) to a grave human rights violation and a part of war crimes and crimes against humanity, torture, and genocide (Alcorn 2014) - to achieve a weaponised status (Leatherman 2011).

This conceptualisation of sexual violence as a 'weapon of war' has become pervasive in much of the media accounts and scholarly work on conflicts, using descriptions such as 'terror tactic' (Peritz and Maller 2014), 'deliberate military strategy' (Smith-Park n.d.), and even as a 'bio-political strategy of war' by which armed combatants symbolically cross enemy lines (Diken and Bagge Laustsen 2005). UN Security Council Resolution 1820 (2008, p. 2) explicitly states that sexual violence is a 'tactic of war', in which civilian populations are deliberately targeted as 'part of a widespread or systematic attack'. Cohen et al. (2013), however, show how sexual violence is often tolerated by armed groups, rather than an intentional strategy of war. So although this term has served to illustrate the 'systematic, pervasive, and orchestrated nature' (Buss 2009, p. 145) of sexual violence in armed conflict, it is nevertheless narrow and incomplete.

For example, Buss (2009) shows how the conceptualisation of sexual violence as an 'instrument of genocide' in Rwanda renders invisible victims other than Tutsi women, such as women and men of Hutu or $\mathrm{Twa}^{3}$ ethnicities. In a similar vein, the weapon of war explanation explains sexual violence as an instrument used by armed combatants, causing violence perpetrated by civilians, such as intimate partners (see, for example, Clark et al. 2010; Freedman 2011; Tayler-Smith et al. 2012) to 'disappear'. Likewise, sexual violence acts committed by UN or African Union (AU) peacekeepers; personnel deployed on UN operations; experts on mission (including military observers); UN volunteers; and contractors, consultants, and police units (see, for example, Burke 2014) become exempted from critical enquiry-let alone sexual violence among humanitarians (see, for example, Norbert 2015a, b).
Whereas some scholars warn that the approach to sexual violence as a weapon of war could backfire (Buss 2014) by increasing its value as a tool to 'fundamentally unravel the fabric of society' (Leatherman 2011, p. 8), the main focus of this paper is that the notion of instrumentality risks designing humanitarian programmes that engage with the limited understanding of sexual violence as perpetrated by armed combatants (Freedman 2014). An example of this is provided by Henttonen et al. (2008), who found that services for sexual violence victims/survivors in northern Uganda exclusively targeted those that had been violated by unknown armed combatants, even though violence from known perpetrators was much more prevalent.

The notion of instrumentality, however, is not the only problematic way in which sexual violence in conflict has been framed by the international community. Indeed, alongside the label 'weapon of war', sexual violence has been repeatedly approached from a (bio)medical standpoint, evident in the popular notion of rape epidemics or even rape pandemics (see, for example, Caspani 2015; or Proudman 2013). Medicalisation tends to reduce sexual violence to an apolitical 'injury', a 'harm done' that has consequently erased the power relations that produce and inform gender - leaving in its place suffering bodies, without perpetrators or causes [emphasis added], each of which can be treated by the universal "humanitarian kit" (Ticktin 2011, p. 251). In that way, the focus is exclusively on the victim/survivor: 'the batterer becomes invisible and so does the problem' (Richters 1998, p. 55). The sexual violence victim/survivor becomes a 'patient, seen in isolation from other injustices or forms of exploitation' (Ticktin 2011, p. 260). Medicalisation thus allows for the decoupling of sexual violence from its sociocultural, economic, and political contexts. Interventions based on medicalisation risk tackling 'the 'symptoms' of violence rather than the underlying 'illness" (Freedman 2014, p. 126).

Slim (2002) explains that humanitarian action necessitates the linking of suffering to innocence, as an 'innocent victim' is 'more likely to generate the giving reflex than an image of people as oppressed rightsbearers demanding a duty from states and peoples across the world' (p. 9). Medicalisation, then, depoliticises the (female) victim/survivor of sexual violence in order to render her, as a recipient of international aid, 'palatable, legitimate, even sympathetic' (Ticktin 2011, p. 260)-not unrelated to the significance placed on sexual integrity, Victorian ideas about the loss of honour, and societal views that blame victims for their own rape (Engle 2014). Medicalisation and consequent depoliticisation have not only allowed victims/survivors of sexual violence to become the "poster child for humanitarian aid' but also connects humanitarian work 
on sexual violence to political neutrality, often crucial for humanitarian actors' access to and relative safety in war zones (Ticktin 2011, pp. 250-251).

Nevertheless, it needs to be said that although medicalisation and depoliticisation are necessary to 'decontaminate' the (in particular) female victim/survivor of sexual violence as to make her 'worthy' of humanitarian assistance in the global south, this may be distinctly different for western women who are raped-especially when the perpetrator is considered as 'the Other'. Very recently, portrayals of sexual violence as an 'epidemic' regained new ground in media accounts of Europe's refugee crisis: titles like 'Europe's rape epidemic: Western women will be sacrificed at the altar of mass migration' (Waters 2015) and 'Rape epidemic in Europe: Why won't European politicians do anything to stop it?' (Snyder 2016) abound. Here, medicalisation seems to emphasise the (perceived) scale of the problem-postulating it as a bio-political strategy of warfare used by 'the enemy'. Here, sexual violence against western women seem to be politicised rather than depoliticised by calling on politicians yet in a way that has the appearance of western men asserting their dominance over 'their' women. Nevertheless, medicalisation directs attention away from the structural inequalities that are so intimately linked to this human rights violation, for both western women and women from the global south. The 'simple' truth is that '[s] exual violence in conflict does not develop in isolation from the society's pre-existing socioeconomic and culturally shaped gender relationships' (Leatherman 2011, p. 3).

The notion of instrumentality, medicalisation, and depoliticisation (of 'Other' women) restricts understanding of sexual violence in armed conflict by failing to reflect the dynamic complexity of this human rights violation. Based on limited understanding, humanitarian assistance focused on protection of refugee and internally displaced person (IDP) communities, or the provision of sexual and reproductive health services for victims/survivors of sexual violence, is bound to be ineffective and inadequate.

\section{Positioning the international humanitarian community: heroic protectors of women and girls}

Understanding the international humanitarian community's response to sexual violence in armed conflict necessitates an analysis of how actors within this community position themselves in relation to the issue, as well as to victims/survivors of sexual violence. Slim (2002) explains that the early conceptualisation of humanitarianism as the 'philanthropic provision of relief' is inherently racist: 'racism which still lingers from colonialism was often comforted rather than challenged by humanitarian marketing and reporting which took a patronising philanthropic view. Many personal acts of humanitarian giving were probably tainted by ideas of African and Asian inferiority that served to infantilise these societies and to dehumanise their people to an almost pornographic extent. Indeed, the very act of giving might often have served to confirm such racism' (p. 10). Although the language of the international humanitarian community has since shifted to a rights-based narrative, aided by the development of international humanitarian law (ibid), it is not unimaginable that these notions still exist, especially when it comes to sexual violence in conflict-where the pain and suffering of others become the source of white, western moral superiority (Razack 2007).

Scully (2009) notes how UN discourses around women in war and sexual and gender-based violence in conflict have an unmistakable emphasis on female vulnerability-reinforcing all too familiar gender stereotypes. Women's vulnerability is subsequently 'compensated' with protection: the 'need to protect women in war' is clearly evident in various Security Council resolutions, such as Resolutions 1820 (2008); 1888 (2009); 1960 (2010); and 2106 (2013) (Engle 2014; Scully 2009). This monotonous rhetoric of the 'vulnerable woman', consistently equated with the 'girl-child', effectively strips her of her agency while simultaneously silencing all discourse around the male victims of sexual violence in armed conflict (Scully 2009). Such discourses ignore warzones' sexually exploited boys as well as civilian men forced to commit acts of sexual violence (Carpenter 2006; Goldstein 1993; Sivakumaran 2007). In northern Uganda, raping men and/or forcing men to rape family members served to further oppress communities by destroying family bonds (Refugee Law Project 2009). One study found that more than one in three male refugees from the DRC had experienced sexual violence in their lifetime (Dolan 2014).

Feminist scholars have argued that early terms from the 1990s, like 'violence against women', although emphasising its structural component, had to make room for the more neutral and objective term 'gender-based violence' (Ertürk 2009; Wieringa 1998). This 'supposed' neutrality, however, according to some, denies the link between historically rooted gender inequality and women's subordination in societies-and violence (Ertürk 2009), by insisting that gender and violence is 'an issue of importance to both men and women' (Wieringa 1998, pp. 367-368). Although Wieringa (1998) maintains that the term 'gender' was adopted to appease those who fear feminist terminology-with the consequence of losing its political and critical potential-in practice, it has made room for the inclusion of male victims/survivors of sexual violence. The male victim/survivor remains nevertheless an elusive subject in the international sexual violence discourse (Lewis 2014), rendering the inclusion argument insincere. Indeed, much still needs 
to be done by the international humanitarian community to address sexual violence against men and boys (Adhiambo Onyango and Hampanda 2011). Moreover, it is exactly sexual violence against men that emphasises the importance of holding on to the link between women's subordination and (sexual) violence. Solangon and Patel (2012) explain that ' $[\mathrm{t}] \mathrm{o}$ rape a man or to sexually violate him is ... to emasculate, feminise or 'homosexualise' the victim' (p. 427). Now, he is considered a woman, and he is now not only subordinate to other men but also subordinate to other men exactly because he is considered a woman (ibid). By using the term gender, sexual (and gender-based) violence loses its intimate link with historically rooted inequality, and women's subordination is thus reproduced by the international humanitarian community.

Similarly, the focus on female vulnerability renders invisible female perpetrators or accomplices in sexual violence, such as the sexual torture of prisoners committed by female United States (US) military personnel at Abu Ghraib prison in Baghdad, Iraq (see, for example, Razack 2005; Richter-Montpetit 2007). Cohen (2013) narrates how female fighters of Sierra Leone's Revolutionary United Front (RUF) actively participated in gang raping. Likewise, sexual violence victims/survivors that fall outside the dichotomy of socially constructed gender identities are disregarded, even though homosexual, bisexual, or transgender individuals may be at particular risk of sexual violence in situations of armed conflict and political instability (Zea et al. 2013). Moving even further away from the female victim/male perpetrator dichotomy in the international sexual violence discourse (Lewis 2014; Linos 2009), Scully (2010) notes how the victim-perpetrator binary essentially overlooks how individuals may be both subjects and agents of violence, like child soldiers who are first victims/survivors of (sexual) violence and later partake in its perpetration. A number of studies refer to sexual violence perpetration as a mechanism for increasing social cohesion among armed groups (Cohen and Nordås 2015). This illustrates again that the complex contexts within which sexual violence occurs are not fully understood.

The simplistic image of the vulnerable woman and girl-child needing protection nevertheless serves as a 'foundational pillar of the Humanitarian Sentiment' (Scully 2009, p. 117). As the vulnerability of the 'Other' (non-western) woman comes at the expense of her power and agency, it seems that the ideas underlying the more recent rights-inspired rhetoric of 'protection' (Slim 2002) are merely a continuation of the undercurrents of racism, paternalism, colonialism, and patriarchal hegemonies of the West (see, for example, Barnett 2012).
In the current-day protectionist narrative of humanitarian action, largely known as the heroic narrative, the (white, male) West is the heroic saviour and guarantor of progressive values such as security, freedom, and peace' (Gurd 2006, p. 30), who brings 'peace and human rights to local communities that need saving' (Benedicto 2005, p. 105). The latter remain a powerless, passive symbol of poverty, violence, and helplessness, oppressed by non-white/non-western oppressors (Benedicto 2005; Gurd 2006; Orford 2003). The nature of these narratives allows us to examine the self-positioning and selfrepresentation of the international humanitarian community in the light of grandiosity-referring to 'attempts to give yourself, your occupational group/ organisation, or even the society in which you live, a positive - if somewhat superficial - well-polished and statusenhancing image' (Alvesson 2013, p. 8).

The international humanitarian community has polished its image (and self-image?) not only through the heroic narrative built on female vulnerability but also through 'inflation of job titles' (Alvesson 2013, p. 10). Although organisational theorist Alvesson presupposes a modest enhancement from 'managers' to 'executives' and 'vice presidents', within the humanitarian community, we speak of 'Special Envoys,' 'High Commissioners,' 'SecretaryGenerals', and 'Special Representative(s) of the SecretaryGeneral(s) for Sexual Violence in Conflict'. Although these titles may very well enhance the image and status of the humanitarian community and of powerful individuals within that community, it nevertheless propels a naming game that escalates the distance in terms of power between a 'High Commissioner' and a 'rape victim' (Benedicto 2005). Whereas 'the bestowment' of humanitarian assistance upon 'beneficiaries' already 'symbolically disempowers the recipients' (Hyndman and de Alwis 2003, p. 218), humanitarians' titles aid in the reproduction of this asymmetric relationship.

The way in which the international humanitarian community positions itself in relation to victims/survivors of sexual violence in armed conflict adds up to a limited understanding of sexual violence. It also obscures humanitarians' complicity: not only directly due to their presence (or absence) in warzones but also indirectly due to the West's involvement in the creation of these conflicts (Benedicto 2005; Orford 2003).

\section{Elephants in the room and complicity: supra-personal perpetrators}

In June 2014, the first-of-its-kind Global Summit to End Sexual Violence in Conflict brought together delegates from more than 120 countries and more than a thousand experts, religious leaders, and representatives of civil society and international organisations to discuss warzone sexual violence. Hollywood actress and 'Special Envoy for 
the UN High Commissioner for Refugees' Angelina Jolie co-chaired the summit with United Kingdom (UK) Foreign Secretary William Hague, united in their 'determination to tackle sexual violence in conflict' (Foreign \& Commonwealth Office UK 2014). In the Statement of Action that followed, sexual violence in conflict is described as 'one of the greatest injustices of our time': 'We stand shoulder to shoulder with all victims and those affected by sexual violence in conflict. We assure them and the communities with which they work that we are committed to providing the support they need and to holding accountable those who perpetrate or are otherwise responsible for these crimes with all means at our disposal' (Foreign \& Commonwealth Office UK 2014, p. 1).

Notwithstanding Jolie's contributions to the field, the Global Summit was a sterling example of how the international humanitarian community increasingly engages with celebrities in what is termed celebrity diplomacy or celebrity humanitarianism. This is not entirely harmless, considering that actors (in the double sense of the word?) often present these issues stripped of their inherent complexity (Engle 2014). Moreover, celebrities recreate the developing world and the people who live in developing countries (including sexual violence victims/ survivors), to put it/them in their proper place in the neoliberal international system through a performative perpetuation of historically embedded subjectivities' (Repo and Yrjölä 2011, p. 44; Mostafanezhad 2013). In a similar vein, the increasing integration of social media into humanitarian campaigns in what Koffman et al. (2015) have termed 'click, donate, and forget campaigns' has not only reframed "helping others' in terms of entrepreneurial and narcissistic self-work' (ibid, p. 158) but also depoliticised humanitarianism by privileging 'privatised action rather than grand ethical and political changes that seek to dismantle global structures of injustice' (Orgad 2012, p. 78). In other words, humanitarians' engagement with celebrities and social media may not originate from a wish to 'stand shoulder to shoulder with all victims and those affected by sexual violence in conflict' but rather serves to further strip sexual violence of its complexity and present it in a way that makes it seem 'solvable'. This raises the question of whether the 'popularisation of human rights' (Engle 2014, p. 34) serves, as suggested by humanitarian organisations themselves, to create support or to create visibility. ${ }^{4}$

The Global Summit undeniably drew substantial and necessary attention towards the topic of sexual violence in conflict. So much so, Zainab Hawa Bangura, 'UN Secretary-General's Special Representative for Sexual Violence in Conflict', noted an 'unprecedented momentum to end sexual violence in conflict' (Bangura 2014). With so many humanitarian power-wielders-governments, donors, and UN agencies-present in one place to talk about one subject, there could have been considerable potential to address some issues that obstruct the effective address of sexual violence (Howard 2014). Yet, this did not happen:

Why, [...] with all these world leaders and health activists gathered to tackle the issue of sexual violence in conflicts, was no one talking about one of the greatest threats to the wellbeing of women raped in conflicts? The panel, which included representatives of the US and UK governments, the United Nations, and the International Committee of the Red Cross, said that it could not comment on the target of [...] inquiry: the 1973 Helms Amendment to the US Foreign Assistance Act. Her question exposed the hypocrisy at the heart of international commitments to support survivors of sexual violence in conflict (ibid, p. 1).

Under the Helms Amendment, US statutory law prohibits the use United States Agency for International Development (USAID) funds to pay for the performance of safe abortion services (Kaiser Family 2016). Even though the Mexico City Policy or 'Global Gag' Rule of 1984 was rescinded by President Barack Obama in 2009 (which obligated organisations to declare non-engagement in the provision of any services related to abortion, even if these services were financed by other funds), the Helms Amendment remains in place, with the consequence that programming 'has been limited by its resistance to purchasing life-saving equipment such as manual vacuum aspiration kits for treatment of incomplete abortions. Overinterpretation of the Helms Amendment has also kept USAID from providing abortion services in situations that are exempted under the prohibition - that is, abortions to save the life of the woman or in cases of rape or incest' (Barot 2011, para 17). US law thus directly interferes with the provision of life-saving services for sexual violence victims/survivors (Howard 2014), even though in the absence of appropriate care, many (raped) women will continue dying from unsafe 'back-street' abortions (Kalonda 2012) or live with often debilitating consequences (Haddad and Nour 2009). Donor restrictions on funding can only be successfully challenged when the international humanitarian community unites in its resistance. Considering the intense competitiveness among humanitarian organisations (Cooley and Ron 2002), this is highly unlikely.

Whereas silences or discursive non-action is unmistakable in the above-mentioned example, in other cases, silences are less straightforward. Despite current acknowledgment of men's and women's differential needs (even with regard to sexual violence), data from peace operations' fieldwork is often not gender-disaggregated 
(Puechguirbal 2010). Gender disaggregation of data would likely lead to the identification of gaps in humanitarian assistance, subsequently obligating organisations to find ways to fill these gaps, with all its financial and political consequences: not challenging the status quo makes decision-makers' lives considerably easier (Puechguirbal 2010). By revealing inequities, the processes that create them are likely to become exposed, and where the international humanitarian community is implicated in creating or reproducing these inequities, there is considerable motivation to not disaggregate data on the basis of gender (Puechguirbal and Enloe 2004).

Another example of the way in which the (dis)organisation of the international humanitarian community contributes to the ineffective address of sexual violence in armed conflict is how '[i]n most cases, NGOs and intergovernmental organisations are investigated by specialists who are paid by their funders and that they sometimes choose' (Pérouse de Montclos 2012, p. 155). Humanitarian agencies' lack of accountability to their 'beneficiaries' or even an external, independent institution takes away evaluation as an opportunity to improve their practices. There may be various incentives for such unhelpful behaviour. Considering the damaging potential of negative evaluations, relief agencies prefer positive evaluations for the continuation of their existence; funding and recipient countries prefer positive evaluations for the validation of their projects; and evaluators prefer filing a positive evaluations because their future employment may depend on it: '[e]ven in-house evaluators, like those who work in the institutionally insulated evaluation department of the World Bank, know that the way to get ahead is not to file too many reports that their agency's projects have failed' (Wenar 2006, p. 19).

In the humanitarian world, where everyone knows everyone, actors within the system are afraid to lose their positions if speaking out; actors outside the system fear that criticising NGOs may cause programmes' discontinuation, to the detriment of their 'beneficiaries' (Pérouse de Montclos 2012). This paradox is sustained through a lack of self-reflexivity that 'erases the conditions of power by which certain knowledges become centralised, seen as self-evident truths, and O/others are excluded, registering as irrational or incomprehensible (impractical: impenetrable). The way hegemony is legitimised and naturalised thus goes unrecognised and is further reinforced' (Gurd 2006, pp. 25-26).

Sometimes, the international humanitarian community's complicity in sexual violence is direct, for example, when sexual violence is perpetrated by NGO personnel or peacekeepers. In other cases, humanitarians' complicity is less direct, not only through fallacious discourses but also through silences. Humanitarian action can only be as effective as its political environment permits it to be: '[w] hen the political context is not right, research is bypassed, evaluations are forgotten, studies are ignored, and aid itself can be curtailed. Wheels are reinvented that, in many cases, never really worked in the first place' (Ramalingam 2013, p. 10). Against this background, women raped upon leaving refugee/IDP camps to collect firewood (see, for example, Patrick 2007) cannot be blamed on the endlessly repeated 'lack of funds and coordination'. These examples illustrate how the organisation of the international humanitarian system seems to be aimed at ensuring its survival rather than to fulfil its promises to those affected by violence.

\section{Conclusion: a case for complexity}

This paper explored how humanitarian discourses about sexual violence in armed conflict systematically simplify sexual violence and strip it of its inherent complexities embedded within socio-cultural, economic, and political realities that inform the inequality underlying sexual violence. The way in which the international humanitarian community positions itself with regard to sexual violence and its victims/survivors serves to support and reinforce a simplified version of sexual violence that can easily be sold to the public. Silences and hypocrisy embedded in the way in which the international humanitarian system is organised further ensures the status quo. This analysis of discourses and silences, combined with the interests that play a role in the international humanitarian arena (especially in the larger institutions and organisations), shows how good intentions are unlikely to be realised. Sexual violence in conflict in particular shows the international humanitarian system at its limits: there is a mismatch between the nature of the issue and the way in which it is understood, leading to the development of programmes on the ground that are out of touch with the complex nature of the problem these programmes try to address (Ticktin 2011; Ramalingam 2013). Indeed, the shortcomings of policies or staff in the field are not to blame, but rather how core concepts around sexual violence in armed conflict have been framed and disseminated within the international humanitarian community (Hyndman and de Alwis 2003).

The question is whether the mismatch between the nature sexual violence in armed conflict, the way in which the international humanitarian community understands it, and the manner in which it is subsequently addressed (or not addressed) in the field is either unintentional or part of the inherent hypocrisy of the international system (Howard 2014). The answer to this question is unlikely to be straightforward. Global development expert Ben Ramalingam (2013) suggests that simplicity, i.e. reductionist philosophy (Occam's razor), underlies much of the aid world, adding up to 'a system where simplicity is repeatedly, 
consistently, and damagingly chosen over relevance and appropriateness' (p. 125). The consequence of this approach is that the issue cannot be effectively addressed (Wieringa 1998), illustrated by '[g]ender [being] treated as a portable tool of analysis and empowerment that can be carried around in the back pockets of both international humanitarian and development staff' instead of a concept that should inform core understanding (Hyndman and de Alwis 2003, p. 212). Simplicity allows humanitarian actors not only relief from the obligation to investigate structural contexts that (re)produce the occurrence of sexual violence in conflict but also exemption from scrutiny in cases where actors are complicit in (re)producing these structural inequalities.

This necessitates a paradigm shift from conventional simplicity thinking to complexity thinking-a way of looking at world problems where interconnectivities, dynamics, and complexities are recognised rather than avoided (Ramalingam 2013), and thus towards a more realistic understanding of the issue (Ramalingam et al. 2008). If humanitarians would engage with complexity thinking, Ramalingam (2013) argues, 'the right questions would be asked rather than the right solutions provided; and organisational learning would be fearless and tireless, characterised by co-evolving and learning with 'beneficiaries' rather than for them: the international humanitarian system would be as open to change on the inside as it was hungry for change outside" (p. 363). This requires (re)linking not only critical research to humanitarian policy (theory) but also theory to practice. That means that researchers have to be willing to fearlessly engage with feminist thinking and give 'gender' back its political and practical potential, by (re)visualising sexuality and the symbolic dimensions of sexual violence in armed conflict (Wieringa 1998). Indeed, 'a disembodied, depoliticised gender discourse hardly holds out the hope for transformation and women's empowerment' (ibid, p. 369; see also Hyndman and de Alwis 2003). Indeed, creating a new humanitarian world requires an increased awareness of the antiquated assumptions that underlie current dominant discourses (Scully 2011). Power, or agency, is in part determined through 'production, accumulation, circulation and functioning of a discourse' (Foucoult 1980, p. 93), which means that the international humanitarian community can $(\mathrm{re})$ create meaning and put it into practice.

\section{Endnotes}

${ }^{1}$ See, for example, the documentation of sexual violence during the First World War (Harris 1993) and Second World War (Burds 2009; Tanaka 2002).

${ }^{2}$ The term victim legally designates an individual who has suffered a human rights violation and who is subsequently entitled to protection and compensation.
The more empowering term survivor, on the other hand, is used to emphasise strength and resilience (UN 2011). In this paper, a combination of these terms, and thus both aspects, is used.

${ }^{3}$ The Twa are a pygmy tribe, a minority ethnic group comprising $1 \%$ of Rwanda's ethnic makeup (Thomson 2009).

${ }^{4}$ See Alvesson (2013) for a discussion on organisations and the role of creating visibility.

\section{Competing interests}

The author declares that she has no competing interests.

\section{Author's information}

The author, RA, holds a BSc in Clinical Psychology from the University of Amsterdam, the Netherlands (2011), and is currently in the process of graduating from the Vrije Universiteit Amsterdam, the Netherlands, with an MSc in Management, Policy Analysis, \& Entrepreneurship in Health and Life Sciences, with a specialisation in International Public Health (2016). The current manuscript is part of the author's master thesis (in the form of an essay) of which the original was titled 'Nothing but good intentions: A critical reflections on the provision of sexual and reproductive health services for survivors of sexual violence in humanitarian emergencies'. The thesis was submitted late-2015 and favourably graded with an 8.5 out of 10 .

The author, RA, is currently discussing a possible PhD position at the Vrije Universiteit Amsterdam, the Netherlands, which will concern empirical research on the same topic: humanitarian responses to sexual violence in armed conflict.

Received: 1 February 2016 Accepted: 13 April 2016

Published online: 30 June 2016

\section{References}

Adhiambo Onyango M, Hampanda K (2011) Social constructions of masculinity and male survivors of wartime sexual violence: an analytical review. Int I Sex Health 23(4):237-247. doi:10.1080/19317611.2011.608415

Ahram Al (2015) Sexual violence and the making of ISIS. Survival 57(3):57-78. doi:10.1080/00396338.2015.1047251

Alcorn T (2014) Responding to sexual violence in armed conflict. The Lancet 383(9934):2034-2037. doi:10.1016/S0140-6736(14)60970-3

ALNAP (2015) The state of the humanitarian system. http://www.alnap.org/ resource/21036.aspx. Accessed 21 Jan 2016

Alvesson M (2013) The triumph of emptiness. Oxford University Press, Oxford

Bangura Z (2014) Unprecedented momentum to end sexual violence in conflict., Thomson Reuters Foundation, http://news.trust.org//item/2014061023201961yqr/. Accessed 1 Feb 2015

Barnett MN (2012) International paternalism and humanitarian governance. Global Constitutionalism 1(3):485-521. doi:10.1017/\$2045381712000135

Barot S (2011) Unsafe abortion: the missing link in global efforts to improve maternal health. Guttmacher Policy Review, 14(2). https://www.guttmacher. org/pubs/gpr/14/2/gpr140224.html. Accessed 30 Jan 2016

Barrow A (2010) UN Security Council Resolutions 1325 and 1820: constructing gender in armed conflict and international humanitarian law. Int Rev Red Cross 92(877):221-234. doi:10.1017/\$1816383110000081

Benedicto B (2005) Reimagining the intervention narrative: complicity, globalisation, and humanitarian discourse. Budhi 9(1):105-117

Berenson T (2014) ISIS's harrowing sexual violence toward Yezidi women revealed. Time. http://time.com/3644943/yezidi-iraq-isis-sexual-violence/. Accessed 27 June 2016

Burds J (2009) Sexual violence in Europe in World War II, 1939-1945. Politics \& Society 37(1):35-73. doi:10.1177/1059601108329751

Burke R (2014) Shaming the state: sexual offences by UN military peacekeepers and the rhetoric of zero tolerance. In: Heathcote G, Otto D (eds) Rethinking peacekeeping, gender equality and collective security. Palgrave Macmillan, London, pp 70-95

Buss DE (2009) Rethinking 'rape as a weapon of war'. Fem Legal Stud 17(2):145-163. doi:10.1007/s10691-009-9118-5

Buss D (2014) Seeing sexual violence in conflict and post-conflict societies: the limits of visibility. In: Buss D, Lebert J, Rutherford B, Sharkey D, Aginam $O$ 
(eds) Sexual violence in conflict and post-conflict societies: international agendas and African contexts. Routledge, London, pp 3-27

Carpenter RC (2006) Recognizing gender-based violence against civilian men and boys in conflict situations. Secur Dialog 37(1):83-103. doi:10.1177/0967010606064139

Caspani M (2015 May 22) Rape on U.S. university campuses reaches 'epidemic' levels_study. Thomson Reuters Foundation. http://www.reuters.com/article/ us-usa-women-rape-idUSKBN00729820150522. Accessed 11 Aug 2015

Chynoweth SK (2008) The need for priority reproductive health services for displaced Iraqi women and girls. Reprod Health Matters 16(31):93-102. doi:10.1016/50968-8080(08)31348-2

Clark CJ, Everson-Rose SA, Suglia SF, Btoush R, Alonso A, Haj-Yahia MM (2010) Association between exposure to political violence and intimate-partner violence in the occupied Palestinian territory: a cross-sectional study. Lancet 375(9711):310-316. doi:10.1016/50140-6736(09)61827-4

Cohen DK (2013) Female combatants and the perpetration of violence: wartime rape in the Sierra Leone Civil War. World Polit 65(3):383-415. doi:10.1353/wp. 2013.0015

Cohen DK, Nordås R (2015) Do states delegate shameful violence to militias? Patterns of sexual violence in recent armed conflicts. J Confl Resolut 56(5):877-898. doi:10.1177/0022002715576748

Cohen DK, Hoover Green A, Wood EJ (2013) Wartime sexual violence: misconceptions, implications, and ways forward., Special report for the United States Institute of Peace, http://www.usip.org/sites/default/files/ resources/SR323.pdf. Accessed 21 Mar 2016

Foreign \& Commonwealth Office UK, (2014) Chair's summary_-Global Summit to End Sexual Violence in Conflict. https:/www.gov.uk/government/publications/chairssummary-global-summit-to-end-sexual-violence-in-conflict/chairs-summaryglobal-summit-to-end-sexual-violence-in-conflict. Accessed 1 Dec 2014

Cooley A, Ron J (2002) The NGO scramble. Int Security 27(1):5-39. doi:10.1162/ 016228802320231217

Diken B, Bagge Laustsen C (2005) Becoming abject: rape as a weapon of war. Body Soc 11(1):111-128. doi:10.1177/1357034X05049853

Dolan C (2014) Into the mainstream: addressing sexual violence against men and boys in conflict. Briefing paper prepared for the workshop held at the Overseas Development Institute, London 14 May 2014. http://www. refugeelawproject.org/files/briefing_papers/Into_The_MainstreamAddressing_Sexual_Violence_against_Men_and_Boys_in_Conflict.pdf. Accessed 17 Mar 2016

Engle K (2005) Feminism and its (dis)contents: criminalising wartime rape in Bosnia and Herzegovina. AJlL 99:778-816

Engle K (2014) The grip of sexual violence: reading UN Security Council Resolutions on human security. In: Heathcote G, Otto D (eds) Rethinking peacekeeping, gender equality and collective security. Palgrave Macmillan, London, pp 23-47

Ertürk Y (2009) Towards a post-patriarchal gender order: confronting the universality and the particularity of violence against women. Sociologisk Forskning 46(4):61-70

Fast $L$ (2010) Mind the gap: documenting and explaining violence against aid workers. Eur J Int Rel 16(3):365-389. doi:10.1177/1354066109350048

Foucoult M (1980) Two lectures. In: Gordon C (ed) Power/knowledge. Selected interviews and other writings 1972-1977. Pantheon Books, New York, pp 78-108

Freedman J (2011) Explaining sexual violence and gender inequalities in the DRC. Peace Rev 23(2):170-175. doi:10.1080/10402659.2011.571601

Freedman J (2014) Treating sexual violence as a "business": reflections on national and international responses to sexual and gender-based violence in the Democratic Republic of Congo. In: Texler Segal M, Demos V (eds) Gendered perspectives on conflict and violence: part B, vol 18B, Advances in gender research. Emerald Group Publishing Limited, Bingley United Kingdom, pp 125-143

Goldstein AT (1993) Recognising forced impregnation as a war crime under international law: a special report of the international programme. The Centre for Reproductive Law \& Policy, New York

Gurd K (2006) Connections and complicities: reflections on epistemology, violence, and humanitarian aid. JIWS 7(3):24-42

Haddad HN (2011) Mobilising the will to prosecute: crimes of rape at the Yugoslav and Rwandan tribunals. Hum Right Rev 12(1):109-132. doi:10.1007/s12142-010-0163-x

Haddad LB, Nour NM (2009) Unsafe abortion: unnecessary maternal mortality. Rev Obstet Gynaecol 2(2):122-126

Hakamies N, Geissler PW, Borchert M (2008) Providing reproductive health care to internally displaced persons: barriers experienced by humanitarian agencies. Reprod Health Matters 16(31):33-43. doi:10.1016/50968-8080(08)31349-4
Harris R (1993) The 'child of the barbarian': rape, race and nationalism in France during the First World War. Past \& Present 141:170-206

Henttonen M, Watts C, Roberts B, Kaducu F, Borchert M (2008) Health services for survivors of gender-based violence in northern Uganda: a qualitative study. Reprod Health Matters 16(31):122-131. doi:10.1016/S0968-8080(08)31353-6

Howard S (2014) Rape in war: how a US law prevents aid for safe abortions. BMJ 349:g5073. doi:10.1136/bmj.g5073

Human Rights Watch (1996) Shattered lives: Sexual violence during the Rwandan genocide and its aftermath. https://www.hrw.org/reports/1996/Rwanda.htm. Accessed 27 June 2016

Hyndman J, de Alwis M (2003) Beyond gender: Towards a feminist analysis of humanitarianism and development in Sri Lanka. WSQ 31(3/4):212-226.

Isis-WICCE (2001) Medical interventional study of war affected Gulu district, Uganda: an Isis-WICCE report. http://isis.or.ug/sites/default/files/ gulumedicalreport.pdf. Accessed 3 December 2014

Jewkes R, Sikweyiya Y, Jama-Shai N (2014) The challenges of research on violence in post-conflict Bougainville. Lancet 383(9934):2039-2040. doi:10.1016/S01406736(14)60969-7

Kaiser Family Foundation (2016) The U.S. Government and international family planning \& reproductive health: statutory requirements and policies. http:// kff.org/global-health-policy/fact-sheet/the-u-s-government-and-internationalfamily-planning-reproductive-health-statutory-requirements-and-policies/. Accessed 26 Jan 2016

Kalonda JC (2012) Sexual violence in Congo-Kinshasa: necessity of decriminalising abortion. Rev Med Brux 33(5):482-486

Koffman O, Orgad S, Gill R (2015) Girl power and 'selfie humanitarianism'. Continuum J Media Cult Stud 29(2):157-168. doi:10.1080/10304312.2015.1022948

Krantz G, Garcia-Moreno C (2005) Violence against women. J Epidemiol Community Health 59:818-821. doi:10.1136/jech.2004.022756

Krause S, Williams H, Onyango MA, Sami S, Doedens W, Giga N, Stone E, Tomczyk B (2015) Reproductive health services for Syrian refugees in Zaatri Camp and Irbid City, Hashemite Kingdom of Jordan: an evaluation of the Minimum Initial Service Package. Conflict and Health 9(Suppl 1):S4

Landegger J, Hau M, Kaducu F, Sondorp E, Mayhey S, Roberts B (2011) Strengths and weaknesses of the humanitarian Cluster Approach in relation to sexual and reproductive health services in northern Uganda. International Health 3:108-114. doi:10.1016/j.inhe.2011.03.005

Leatherman JL (2011) Sexual violence and armed conflict. Polity Press, Cambridge

Lewis C (2014) Systematic silencing: addressing sexual violence against men and boys in armed conflict and its aftermath. In: Heathcote G, Otto D (eds) Rethinking peacekeeping, gender equality and collective security. Palgrave Macmillan, London, pp 203-223

Linos N (2009) Rethinking gender-based violence during war: is violence against civilian men a problem worth addressing? Soc Sci Med 68(8):1548-1551. doi: 10.1016/j.socscimed.2009.02.001

Longombe AO, Claude KM, Ruminjo J (2008) Fistula and traumatic genital injury from sexual violence in a conflict setting in Eastern Congo: case studies. Reprod Health Matters 16(31):132-141. doi:10.1016/S0968-8080(08)31350-0

Marsh M, Purdin S, Navani S (2006) Addressing sexual violence in humanitarian emergencies. Glob Public Health 1(2):133-146. doi:10.1080/17441690600652787

McGinn T (2009) Barriers to reproductive health and access to other medical services in situations of conflict and migration. In: Forbes Martin S, Tirman J (eds) Women, migration, and conflict. Springer, London, pp 129-143

Mostafanezhad M (2013) 'Getting in touch with your inner Angelina': celebrity humanitarianism and the cultural politics of gendered generosity in volunteer tourism. Third World Q 34(3):485-499. doi:10.1080/01436597.2013.785343

Norbert M (2015a) Aid worker: I was drugged and raped by another humanitarian in South Sudan., The Guardian, http://www.theguardian.com/ global-development-professionals-network/2015/jul/29/aid-worker-rapehumanitarian-south-sudan-sexual-violence/. Accessed 30 Jan 2016

Norbert M (2015b) Sexual assault against aid workers: it's time to take a stand., The Guardian, http://www.theguardian.com/global-developmentprofessionals-network/2015/aug/19/sexual-assault-rape-against-aid-workerits-time-to-take-a-stand. Accessed 30 Jan 2016

Orford A (2003) Reading humanitarian intervention: human rights and the use of force in international law. Cambridge University Press, Cambridge

Orgad S (2012) Media representation and the global imagination. Polity Press, Cambridge

Palmer CA, Lush L, Zwi AB (1999) The emerging international policy agenda for reproductive health services in conflict settings. Soc Sci Med 49(12): 1689-1703. doi:10.1016/50277-9536(99)00253-1 
Patrick E (2007) Sexual violence and firewood collection in Darfur. FMR 27:40-41 Peritz A, Maller T (2014) The Islamic state of sexual violence., Foreign Policy, http://foreignpolicy.com/2014/09/16/the-islamic-state-of-sexual-violence/. Accessed 31 Jan 2016

Pérouse de Montclos MA (2012) Humanitarian action in developing countries: who evaluates who? Eval Program Plann 35(1):154-160. doi:10.1016/j. evalprogplan.2010.11.005

Proudman CR (2013) War rape: the forgotten pandemic sweeping Syria., The Independent, http://www.independent.co.uk/voices/comment/war-rape-theforgotten-pandemic-sweeping-syria-8460566.html. Accessed 11 Aug 2015

Puechguirbal N (2010) Discourses on gender, patriarchy and resolution 1325: a textual analysis of UN documents. Int Peacekeeping 17(2):172-187. doi:10. 1080/13533311003625068

Puechguirbal N, Enloe C (2004) Failing to secure the peace: practical gendered lessons from Haiti \& Iraq. http://genderandsecurity.org/sites/default/files/ nadine_puechguirbal_and_cynthia_enloe_consortium_lecture_10-26-2004. pdf. Accessed 1 Feb 2015

Qayum M, Arooj H, Mohmand S (2013) Minimum Initial Service Package (MISP) access to displaced people of Pakistan based on Sphere standards and indicators. J Pak Med Assoc 63(8):1027-1030

Ramalingam B (2013) Aid on the edge of chaos. Oxford University Press, Oxford

Ramalingam B, Jones H, Reba T, Young J (2008) Working Paper 285: Exploring the science of complexity: ideas and implications for development and humanitarian efforts (2nd ed). http://www.odi.org/sites/odi.org.uk/files/odiassets/publications-opinion-files/833.pdf. Accessed 30 Oct 2015

Razack S (2005) How is white supremacy embodied? Sexualised racial violence at Abu Ghraib. CJWL 17(2):134-363

Razack SH (2007) Stealing the pain of others: reflections on Canadian humanitarian responses. REPCS 29(4):375-394. doi:10.1080/10714410701454198

Refugee Law Project (2009) Gender against men. http://www.forcedmigration.org/ podcasts-videos-photos/video/gender-against-men. Accessed 7 Mar 2016

Remarks at the launch of the international protocol (2014) News Story. UK Government Foreign \& Commonwealth Office. https://www.gov.uk/ government/news/remarks-at-the-launch-of-the-international-protocol-2. Accessed 2 Dec 2014

Repo J, Yrjölä R (2011) The gender politics of celebrity humanitarianism in Africa. Int Feminist J Polit 13(1):44-62. doi:10.1080/14616742.2011.534661

Richter-Montpetit M (2007) Empire, desire and violence: a queer transnational feminist reading of the prisoner 'abuse' in Abu Ghraib and the question of gender equality. Int Feminist J Polit 9(1):38-59. doi:10.1080/14616740601066366

Richters A (1998) Sexual violence in war: psychosociocultural wounds and healing processes: the example of the former Yugoslavia. Session 4. Addressing the issue of violence against women in war situations. European strategies to combat violence against women. Report of the first technical meeting. Copenhagen, Denmark, 11-13 December 1997. http://www.euro.who.int/_ data/assets/pdf_file/0004/119173/E61935.pdf. Accessed 7 Jan 2016

Scully P (2009) Vulnerable women: a critical reflection on human rights discourse and sexual violence. Emory Int L Rev 23:113-123

Scully P (2010) Expanding the concept of gender-based violence in peacebuilding and development. JPD 5(3):21-33. doi:10.1080/15423166.2010.735076776752

Scully P (2011) Gender, history, and human rights. In: Hodgson DL (ed) Gender and culture at the limit of rights. University of Pennsylvania Press, Philadelphia, pp 17-31

Seybolt TB (2009) Harmonising the humanitarian aid network: adaptive change in a complex system. Int Stud Q 53(4):1027-1050. doi:10.1111/j.1468-2478.2009.00567.x

Sivakumaran S (2007) Sexual violence against men in armed conflict. Eur J Int Law 18(2):253-276. doi:10.1093/ejil/chm013

Slim H (2002) Not philanthropy but rights: the proper politicisation of humanitarian philosophy. The Int J Hum Rights 6(2):1-22. doi:10.1080/714003759

Smith-Park L (n.d.) How did rape become a weapon of war? BBC News. http:// news.bbc.co.uk/2/hi/4078677.stm. Accessed 31 Jan 2016

Snyder M (2016) Rape epidemic in Europe: why won't European politicians do anything to stop is? Infowars. http://www.infowars.com/rape-epidemic-in-europewhy-wont-european-politicians-do-anything-to-stop-it/. Accessed 31 Jan 2016

Solangon S, Patel P (2012) Sexual violence against men in countries affected by armed conflict. CSD 12(4):417-442. doi:10.1080/14678802.2012.724794

Stearns J (2009) Are we focusing too much on sexual violence in the DRC? http://congosiasa.blogspot.nl/2009/12/are-we-focusing-too-much-on-sexual.html. Accessed 1 Feb 2015

Tanaka Y (2002) Japan's comfort women: Sexual slavery and prostitution during World War II and the US occupation. Routledge, London.
Tayler-Smith K, Zachariah R, Hinderaker SG, Manzi M, de Plecker E, van Wolvelaer P, Gil T, Goetghebuer S, Ritter H, Bawo L, Davis-Worzi C (2012) Sexual violence in post-conflict Liberia: survivors and their care. TMIH 17(11):1356-1360. doi:10.1111/j.1365-3156.2012.03066.x

Thomson SM (2009) Ethnic Twa and Rwandan national unity and reconciliation policy. Peace Rev 21(3):313-320. doi:10.1080/10402650903099377

Ticktin M (2011) The gendered human of humanitarianism: medicalising and politicising sexual violence. Gend Hist 23(2):250-265. doi:10.1111/j.1468-0424. 2011.01637.x

United Nations (2011) OHCHR Manual on human rights monitoring. Chapter 12: trauma and self-care. http://www.ohchr.org/Documents/Publications/ Chapter12-MHRM.pdf. Accessed 30 Jan 2016

United Nations Office for the Coordination of Humanitarian Affairs (UNOCHA) (n.d.) Cluster Coordination. http://www.unocha.org/what-we-do/coordination-tools/ cluster-coordination. Accessed 9 Jan 2016

UN Security Council, Security Council resolution 1820 (2008) [on acts of sexual violence against civilians in armed conflicts], S/RES/1820 (2008). http://www. refworld.org/docid/485bbca72.html. Accessed 27 June 2016

UN Security Council, Security Council resolution 1888 (2009) [on acts of sexual violence against civilians in armed conflicts], S/RES/1888 (2009). http://www. refworld.org/docid/4ac9aa152.html. Accessed 27 June 2016

UN Security Council, Security Council resolution 1960 (2010) [on women and peace and security], S/RES/1960 (2010). http://www.refworld.org/docid/ 4d2708a02.html. Accessed 27 June 2016

UN Security Council, Security Council resolution 2106 (2013) [on sexual violence in armed conflict], S/RES/2106 (2013). http://www.refworld.org/docid/ 51d6b5e64.html. Accessed 27 June 2016

Walker P, Maxwell DG (2009) Shaping the humanitarian world. Routledge, New York

Waters A (2015) Europe's rape epidemic: western women will be sacrificed at the altar of mass migration., Breitbart, http://www.breitbart.com/london/2015/10/ 06/europes-rape-epidemic-western-women-will-be-sacrificed-at-the-alter-ofmass-migration/. Accessed 31 Jan 2016

Wayte K, Zwi AB, Belton S, Martins J, Martins N, Whelan A, Kelly PM (2008) Conflict and development: challenges in responding to sexual and reproductive health needs in Timor-Leste. Reprod Health Matters 16(31):83-92. doi:10.1016/S0968-8080(08)31355-X

Wenar L (2006) Accountability in international development aid. Ethics Int Aff 20(1):1-23. doi:10.1111/j.1747-7093.2006.00001.x

Wieringa SE (1998) Rethinking gender planning: a critical discussion of the use of the concept of gender. Gend Technol Dev 2(3):349-371. doi:10.1177/ 097185249800200301

Zea MC, Reisen CA, Bianchi FT, Gonzales FA, Betancourt F, Aguilar M, Poppen PJ (2013) Armed conflict, homonegativity and forced internal displacement: implications for HIV among Colombian gay, bisexual and transgender individuals. Cult Health Sex 15(7):788-803. doi:10.1080/13691058.2013.779028

\section{Submit your manuscript to a SpringerOpen ${ }^{\circ}$ journal and benefit from:}

- Convenient online submission

- Rigorous peer review

- Immediate publication on acceptance

- Open access: articles freely available online

- High visibility within the field

- Retaining the copyright to your article

Submit your next manuscript at $>$ springeropen.com 